\title{
Reviews
}

\section{Branislav Anđelković, Nicoleta Demian, Colecția de antichități egiptene a Muzeului Banatului din Timișoara/ The Collection of Egyptian Antiquities in the Museum of Banat in Timișoara, Bibiotheca Historica et Archaelogica Banatica LVIII, Ancart Publishing House, Timișoara 2016, 135 p.}

When it comes to the subject of Egyptology in Romania, one may easily notice that it is far behind other countries of South-Eastern Europe, with only a handful of scientits having to deal with this field of Ancient History $^{1}$. However, there are some important collections of artifacts acquired throughout time which are now housed by different cultural institutions in Romania ${ }^{2}$.

The catalogue of the Egyptological collection of the Museum of Banat is undoubtedly useful and is only the second scientific endevour of this kind ever to have been published in Romania ${ }^{3}$.

The work is divided in two main parts: the first part is the critical analysis of the artifacts by Branislav Anđelković (Chapters I-XI), while the second part was the contribution of Nicoleta Demian, who offers information on the history of the collection itself (Chapter XII) as we are informed early in the introduction (p. 7, note 1). Both parts are written in Romanian and English as well. In the following lines, I will offer a short presentation of this catalogue together with some additional notes when it is required.

Chapter I. Introduction (p. 7-9) sets the frame of the birth of Egyptology and also offers a glimpse of collectors and donors in the Balkans, an area called "the margin of the mainstream world" (p. 8). It ends with a brief presentation of the collection and the various impediments encountered by the study of these artefacts.

The following chapters (Ch. II-XI) are composed by the analysis of 52 artifacts which are part of the collection of the Museum of Banat. They are divided in ten categories, each and every category being included in one particular chapter.

Chapter II. Amulets starts with a short introduction of the use of amulets in Ancient Egypt, the main bibliography (p. 10-11), followed by a presentation of the deities portrayed on the amults (p. 12-28): no. 1 Nefertum; no. 2 Shu; no. 3 Isis lactans ${ }^{4}$; no. 4 Thoth; no. 5 Nut; no. 6-8 Bes; no. 9-12 Taweret ${ }^{5}$; no. 13-14 Anubis) of the collection and other magical symbols, no. 15 the wedjat-eye and no. 16 and 17 the White and respectively the Red Crowns amulets. It should be noted that all amulets are described and

1 See TOMORAD 2015 for the field of Egyptology in South-Eastern Europe.

2 For a short review of the published collections see the paper DEAC 2015, 117-119 from the above mentioned book.

3 For the previous reference see: GLODARIU et alii 1988. It should be mentioned that some of the artifacts of the Museum of Banat were previously mentioned in this catalogue as can be seen in the artifacts' individual presentations.

${ }^{4}$ See also for this iconographycal hypostasis in the Roman period see in- and outside Egypt see: TRAN TAM TINH 1973.

5 For a similar representation found in Roman context in Aquincum (Pannonia Inferior) see: DOBROVITS 1943, 55, fig. 3.1 .

\section{Dan Deac}

History and Art County Museum of Zalău dan_deac1923@yahoo.com

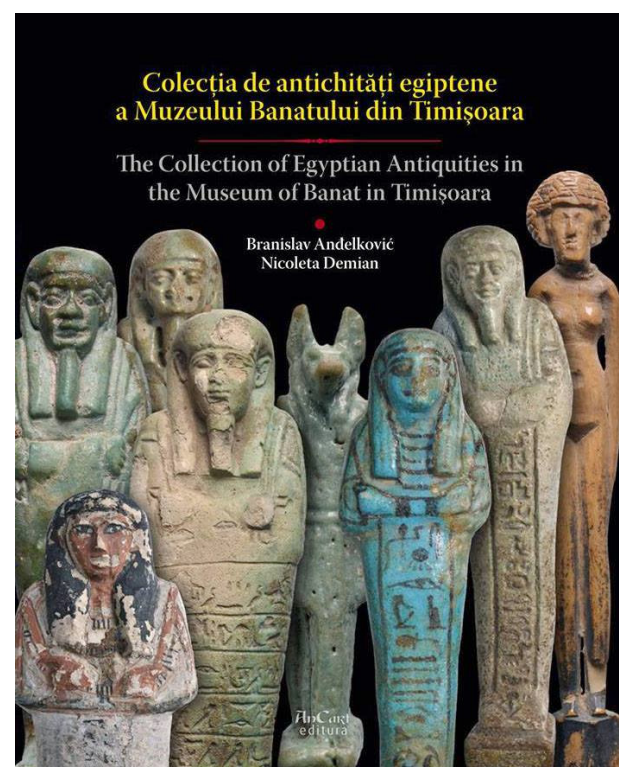

DOI: $10.14795 /$ j.v4i1.224

ISSN $2360-266 \mathrm{X}$

ISSN-L 2360 - 266X 
included in an iconographical frame, followed by the kind of material- which is burnt clay covered with fayence of green or yellowish colour- the dimensions, dating, the inventory number, and the historical backround of how the artifacts ended up in the collection of the museum. Unfortunately, the provenience is unknown for all of the amulets which makes the provenence field of every artifact superflous for this category.

Chapter III. Scarabs and Scaraboids is initiated by a presentation of scarabs and scaraboids in Ancient Egypt, their use, and the difference between the two terms (p. 2930). Next comes the analysis of the five scarabs in a similar fashion as the previous type of artifacts (p. 31-38, no. 18-22). The scarabs date in the time frame from the $18^{\text {th }}$ to the $22^{\text {nd }}$ Dynasty, originating from a tomb in Luxor and respectively Memphis (no. 18 and no. 22). The scaraboid (no. 23) it treated separately and dates somewhere between the Second Intermediate Period and the New Kingdom, presumably being found in a stone sarcophagus in Luxor in 1874.

Chapter IV. Shabties are twelve in number, making the collection from Timișoara the biggest of its kind in Romania. Followed by a short but coincise introduction of this kind of funerary statuettes (p. 39), the artifacts are presented (p. 40-64, no. 24-36), by each having a description, the translation of the preserved hieroglyphic inscriptions, the material of which they are made of, dimensions, dating, provenence, registration number, historical backround and previous publication. The typological identification after Hans D. Schneider ${ }^{6}$ is made possible through footnotes; however a more adequate way would have been by creating a separate field of typology.

Chapter V. Statuettes comprises of an introductory note (p. 65) and three statuettes: two bronze statuettes of mumiform Osiris (p. 66-69, no. 37-38) and a bone statuette of a woman (p. 70-71 no. 39), none of them having a certain provenance. It should be noted that the bronze statuette no. 38 was considered by the authors either as a Roman copie or a modern forgery (p. 68). However these kind of statuettes were used as amulets that were worn upside down for an unknown reason, but were very common in the Danubian provinces, for example in Dacia?.

The following two chapters are represented each by one artifact. Chapter VI. Statue (p. 72-74, no. 40) offers us a man`s head of a granite statue dated between the reigns of Tuthmosis III and Amenhotep II, originating in Thebes. Chapter VII. Headrest is represented as the title shows by a headrest made out of wood dated in a wide time spam from the New Kingdom to the Ptolemaic period (p. 75-77, no. 41). This is the first example of this type of artifacts known to have been housed in Romania (for an introductory note see p. 75).

A large portion of the catalogue is reserved to the wooden sarcophagus and the mortuary mask in Chapter VIII. Coffin and Coffin Face. As usual, the analysis of the artifacts (p. 79-96, no. 42-43) is preceeded by an introductory note where it is stated that the two artifacts are not related to eachother (p. 78, note 67). It should be noted-as stated in the

\footnotetext{
See SCHNEIDER 1977.

See NEMETI 2010, 279-282, pl. I. for example for Dacia. Still the subject has to be discussed further in the future.
}

catalogue- that the fragmentary wooden parts of the coffin are part of a wooden coffin dating in the $21^{\text {st }}$ Dynasty ${ }^{8}$. After the publication of this catalogue an AMS dating technique of the wooden coffin was undertaken showing that the wood was cut down around the middle of the $11^{\text {th }}$ century $\mathrm{BCE}^{9}$.

Chapter IX. Vessels and Lamps can be divided into several parts. This proposed approach is advanced because the artifacts should have been divided into the Ancient Egyptian period and the Graeco-Roman one. After the introduction (p. 97), a clay miniature vessel dating in the Old Kingdom (p. 98, no. 44) and a small steatite jar are presented (p. 99, no. 45). The Graeco-Roman era artifacts follow: the glass ampulla (p. 100, no. 46) ${ }^{10}$ and the Frog-type lucernae (p. 101-103, no. 4749). For some of the artifacts some observations have to be made. No. 47 has a mark in the form of alpha and dates in the $3^{\text {rd }}-4^{\text {th }} C E^{11}$ while no. 48 has a mark ISI specific to a possible Alexandrian production center or one from the Delta and dates in the first half of the $1^{\text {st }}$ c. $C E^{12}$.

Chapter X. Textiles is represented by two badly preserved fragments (p. 104-106, no. 50a-b).

Chapter XI. Mummies consists of a presentation of the mummification techniques and types of mummifications and shows how the crocodile mummy (p. 110-111 no. 52) was a votive offering to the crocodile God Sobek while the other fragment was a part of a right foot of a human mummy (p. 109, no. 51).

Finally Chapter XII. History of the Collection recreated from scratch the history of the collection, divided into four time frames: 1 . The historical context and the birth of the Museum in Timișoara (p. 112-113); 2. The creation of the Egyptian collection starting in 1879 (p. 113-117); 3. The climax reached during the lifetime of Max Herz Bey (p. 117121); 4. The ,,adventures” that the collection had from 1909 until our present day (p. 122-125).

In the end the fifth part of the chapter- as a sort of an appendix- enlists a hall of fame of the most important donors: Dr. Berkeszi István, Bleyer Izsó, Emil Folly, Maximilian Herz, Láng Lehel, Ormós Zsigmond and Pongrácz Imre (p. 125129). Out of these personalities Maximilian Herz, who lived for 34 years in Egypt, stands out (1856-1919) ${ }^{13}$.

The catalogue ends with a useful chronological table directed especially to the non-specialists and amateurs of the history of Egypt (p. 130), a list of figures (p. 131-132) and a rather rich bibliography (p. 133-135).

Some final remarks have to be made. The catalogue of the Egyptian collection from the Museum of Banat from Timisoara shows undoubtedly that this is one of the most important collection of its type known in Romania. The expertise and the meticulousness of the authors in the process of publishing this collection and of tracing back its history in the $19^{\text {th }}$ century makes this catalogue a very important tool for the study of Egyptology in Romania, and

The other part is in the Museum of Fine Arts in Budapest, see: ANDELKOVIĆ/TEETER 2015, p. 209-221.

9 See for a detalied interdisciplinary analysis STANCOVICI/DIACONESCU 2016, p. 183-219, in particular 186-187.

10 See HARDER 1936 for a useful collection of Roman era glass ware found in Karanis.

11 BAILEY 1988, p. 264 similar to Q 2183 in his catalogue.

12 BAILEY 1988, p. 220 and 239, Q 1959 in his catalogue.

13 For period he activated in Egypt and his great endevours in this area see: REID 2002. 
it boosts itself as a landmark for the study of future such collections housed in other institutions scattered all around the country.

In 1922 Lord G. H. Carnavon asked Howard Carter if he saw anything while making a hole in the doorway entrance of Tutankhamon`s tomb. The later famously replied: Yes, wonderful things! ${ }^{14}$ It is my utter most desire and hope that whoever will have the opportunity to read and even see for him/herself the collection at the Museum of Timișoara will have the chance to reply at the end in the same manner as Howard Carter once did.

\section{REFERENCES}

ANDELKOVIĆ/TEETER 2015

Anđelković, B./Teeter, E./Coffin, A., Dispersed: Case Study of $21^{\text {st }}$ Dynasty Coffin Fragments (Timișoara 1142-1146, Budapest 51.325). Issues in Ethnology and Anthropology (n.s.) 10/1, 209-221.

BAILEY 1988

Bailey, D. M., Lamps in the British Museum. III Roman Provincial Lamps (London: Trustees of the British Museum).

CARTER/MACE 1923-1933

Carter, H./Mace, A. C., The Tomb of Tut Ankh Amen, vol. I (London).

DEAC 2015

Deac, D. A., Ancient Egyptian Artifacts from Romania. Their Research and Future Perspectives. In: M. Tomorad (ed.), Research of history and culture of Ancient Near East and Ancient Egypt in Southeastern Europe. Archaeopress Egyptology 8 (Oxford: Archaeopress), 117-119.

DOBROVITS 1943

Dobrovits, A., Az Egyptomi Kultuszok Emlékei Aquincumban, Budapest Regiszegei 13, 47-75.

GLODARIU ET ALII. 1988

Glodariu, E. et alii Antichități egiptene în muzeele din România (Cluj-Napoca) (exihibition catalogue).

HARDER 1936

Harder, D. B., Roman Glass from Karanis found by the University of Michigan Archaeological Expedition in Egypt, 1924-29 (Ann Arbor: University of Michigan Press).

NEMETI 2010

Nemeti, I., Osiris in Dacia. In: Angelescu, M. V./Achim, I./ Bâltâc, A./Rusu Bolindeț, V./Botez, V. (eds.), Antiquitas Istro-Pontica. Mélanges d archéologie et d'histoire ancienne offerts à Alexandru Suceveanu (Cluj-Napoca: Mega), 279282.

REID 2002

Reid, D. M., Whose Pharaohs? Archaeology, Museums, and Egyptian National Identity from Napoleon to World War I (Berkeley, Los Angeles, London: University of California Press).

\section{SCHNEIDER 1977}

Schneider, H. D., Shabtis - An Introduction to the History of Ancient Egyptian Funerary Statuettes with a Catalogue of the Collection of Shabtis in the National Museum of Leiden, 3 vols (Leiden: Rijksmuseum van Oudheden).

\section{STANCOVICI/DIACONESCU 2016}

Stancovici, D./Diaconescu, D., AMS Dating of an Artifact from Banat Museum's Egyptian Collection and Remarks Regarding the Preservation Status, Analele Banatului XXIV, 2016, 183-219.

TOMORAD 2015

Tomorad, M. (ed.), Research of history and culture of Ancient Near East and Ancient Egypt in Southeastern Europe.
Archaeopress Egyptology 8 (Oxford: Archaeopress).

TRAN TAM TINH 1973

Tran Tam Tinh, V., Isis lactans. Corpus des monuments grecoromains d'Isis allaitant Harpocrate. Études Préliminaires aux Religions Orientales dans l'Empire Romain 37 (Leiden: Brill).

\footnotetext{
${ }^{14}$ CARTER/MACE 1923-33, 96.
} 